\title{
Social recognition memory requires two stages of protein synthesis in mice
}

\author{
Karin Richter, Gerald Wolf, and Mario Engelmann ${ }^{1}$ \\ Otto-von-Guericke-Universität, Institut für Medizinische Neurobiologie, D-39120 Magdeburg, Germany
}

\begin{abstract}
Olfactory recognition memory was tested in adult male mice using a social discrimination task. The testing was conducted to begin to characterize the role of protein synthesis and the specific brain regions associated with activity in this task. Long-term olfactory recognition memory was blocked when the protein synthesis inhibitor anisomycin was injected 20 min before, immediately after, or $6 \mathrm{~h}$ after sampling. No effect was observed when anisomycin was administered $3 \mathrm{~h}$ or $18 \mathrm{~h}$ after sampling. Immunohistochemical analysis of Fos expression revealed that sampling-like exposure to a juvenile increased the activity of a subset of cells in the accessory olfactory bulb and the brain areas that are associated with it. Additionally, increased Fos expression was measured in the main olfactory bulb and the piriform cortex, whereas no signs of activation were seen in the cortical nucleus of the amygdala, all components of the main olfactory system. No increases in Fos immunoreactivity were observed after $4 \mathrm{~h}$. Our data suggest that long-lasting olfactory recognition memory requires two stages of protein synthesis. The first stage takes place within 1-2 $\mathrm{h}$ and the second stage between 6-7 $\mathrm{h}$ after sampling. The first but not the second stage is paralleled by an increase in the number of Fos-immunoreactive cells in brain areas associated with both the main and accessory olfactory systems. It therefore appears that the role of the second stage of protein synthesis in recognition memory depends on the integrity of the first stage of protein synthesis.
\end{abstract}

Evidence has accumulated showing that long-term memory storage requires protein synthesis (Freeman et al. 1995; Rose 1995; Quevedo et al. 1999; Rose and Stewart 1999). However, in the search for the molecular constituents of such a "memory trace" in the brain, the behavioral tasks used have focused on associative learning (e.g., fear conditioning and avoidance learning). Under certain conditions it has also been reported that two or more stages of protein synthesis are involved in memory consolidation (Grecksch and Matthies 1980; Freeman et al. 1995; Quevedo et al. 1999; Ressler et al. 2002). However, classical (fear) conditioning and avoidance learning require negative reinforcement. This makes it difficult to dissociate the brain areas that are involved in the stimulus association and those which are primarily engaged in the emotional processing of the conditioned and unconditioned stimuli (Imaki et al. 1993; Duncan et al. 1996; Beckett et al. 1997). It is therefore important to investigate learning paradigms that do not require aversive stimuli such as shock.

Recognition memory refers to the ability of animals and humans to discriminate between familiar and unfamiliar stimuli. Among the different laboratory tasks used to investigate recognition memory in rats and mice, the social recognition/social discrimination task has several advantages. For instance, this task does not require the application of additional stimuli in order to provoke the behavioral response used as an index for the memory performance (Dantzer et al. 1987; Engelmann et al. 1995). More specifically, the task takes advantage of the innate drive of an adult animal to investigate nonfamiliar over familiar conspecifics. Both rats and mice are macrosmates for which storage and recall of information acquired by olfaction is a prerequisite for a successful interaction with the living and nonliving world (Eibl-Eibesfeldt 1950, 1952). This implies that studies in-

\footnotetext{
1Corresponding author.

E-mail mario.engelmann@medizin.uni-magdeburg.de; fax 49391 6714365.

Article and publication are at http://www.learnmem.org/cgi/doi/10.1101/ Im. 97505 .
}

vestigating the processing of such information provide a privileged access to learning and memory in these species.

Two different neuronal systems have evolved for the processing of olfactory cues: Information about volatile stimuli is preferentially processed in the main olfactory system (MOS), and information about nonvolatile stimuli is preferentially processed in the accessory olfactory system (AOS; Fig. 1). The MOS is comprised of the main olfactory bulb (MOB) and limbic structures, such as the cortical nucleus of the amygdala and the piriform cortex (Cooke et al. 1998). The AOS, in contrast, consists of the accessory olfactory bulb (AOB) including its mitral and granular cell subdivisions associated with the medial nucleus of the amygdala, the bed nuclei of the lateral olfactory tract and of the stria terminalis, the medial preoptic area, and the septum (Cooke et al. 1998).

Performance on the social recognition/social discrimination task requires olfactory information. Male mice are able to store the "olfactory signature" of a given conspecific for at least $7 \mathrm{~d}$ (Kogan et al. 2000). This implies that this species is able to establish a long-term olfactory memory, which has been reported to depend on protein synthesis (Kogan et al. 2000). The present study investigated the role of both olfactory systems (AOS, MOS) in juvenile recognition using early onset of gene expression (Fos) (Sagar et al. 1988) and the time-course of memory-related protein synthesis.

\section{Results}

\section{Olfactory recognition}

As shown in Figure 2B,C, mice were able to discriminate for $24 \mathrm{~h}$ between an already encountered familiar conspecific and a new juvenile. We refrained from testing longer retention intervals (RIs), as extending the separation causes highly aggressive behavior if the experimental subjects would be returned to their original groups of five (M. Engelmann, unpubl.). Group housing reduces aggressive behavior of the adults towards the juveniles and per- 


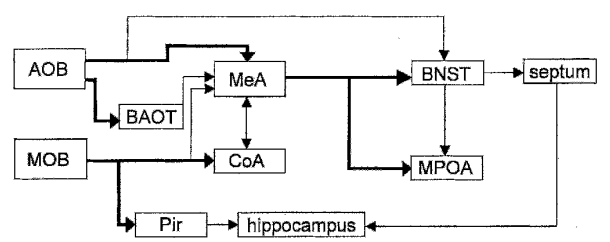

Figure 1. Main afferent areas processing olfactory information in the rodent brain. Nonvolatile stimuli are processed predominantly via the accessory olfactory bulb (AOB), volatile stimuli via the main olfactory bulb (MOB). BAOT, bed nucleus of the lateral olfactory tract; Pir, piriform cortex; MeA, medial nucleus of the amygdala; $\mathrm{CoA}$, cortical nucleus of the amygdala; BNST, bed nucleus of the stria terminalis; MPOA, medial preoptic area. Modified after Cooke et al. (1998).

mits repeated testing in the same animal (e.g. as its own control), which is a major advantage of the social discrimination procedure.

Administration of anisomycin (ANI) 20 min before sampling caused a general reduction in the duration of investigatory behavior both during sampling and choice $1 \mathrm{~h}$ later (Fig. 3A). Nevertheless, mice treated with ANI were able to recognize the familiar juvenile $1 \mathrm{~h}$ after sampling (Fig. 3B). However, the same treatment interfered with the juvenile recognition abilities assessed $24 \mathrm{~h}$ after sampling (Fig. 4A). To test whether this effect was due to the observed nonspecific reduction of the investigatory curiosity caused by ANI, we performed an additional session in which we allowed each mouse to investigate the juvenile during sampling only for exactly the same time it explored the juvenile under ANI treatment. Under these conditions animals were able to recognize $24 \mathrm{~h}$ after sampling the previously exposed juvenile (Fig. 4A, right panel). This suggests that the nonspecific ANI action does not explain the impaired long-term recognition memory seen $24 \mathrm{~h}$ after ANI treatment. Indeed, when a separate
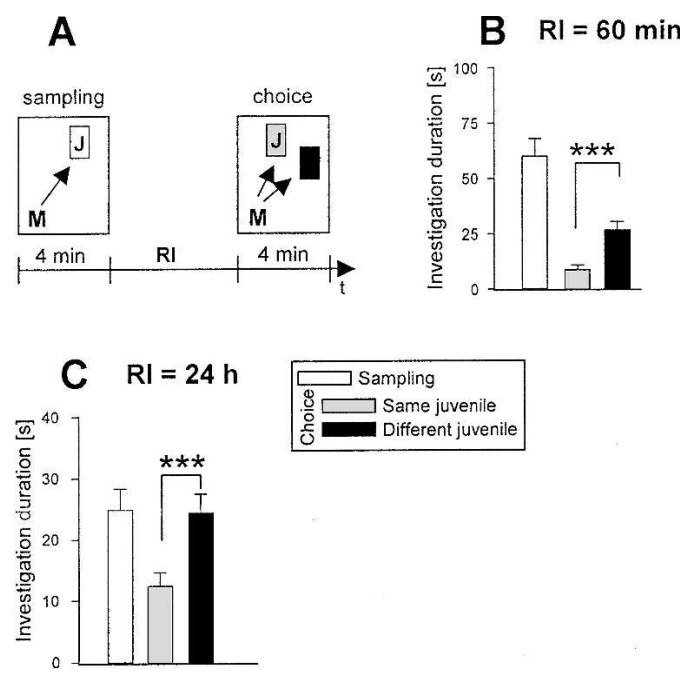

Figure 2. Olfactory recognition memory performance as a function of the retention interval (RI) of adult male mice was tested in the social discrimination procedure. $(A)$ The principle of the social discrimination test. A conspecific juvenile (letter " $\mathrm{J}$ " in white box) is exposed to an adult male mouse $(A)$ during a 4 -min sampling period. This juvenile is removed and after a given $\mathrm{Rl}$ it is re-exposed during the choice session (" $\mathrm{J}$ " in gray box) but this time together with a different, nonfamiliar juvenile ("J" in black box). The duration taken by the adult to investigate the juvenile(s) (represented by arrows) is measured by a trained observer and expressed separately for each juvenile as the "investigation duration." At Rls of 60 $(B)$ and $24 \mathrm{~h}(C)$, during "choice", mice are able to discriminate a juvenile exposed earlier (during sampling, "same juvenile") from a different juvenile (left panels). ${ }^{*} P<0.05,{ }^{* * *} P<0.001$, paired Student's $t$-test.
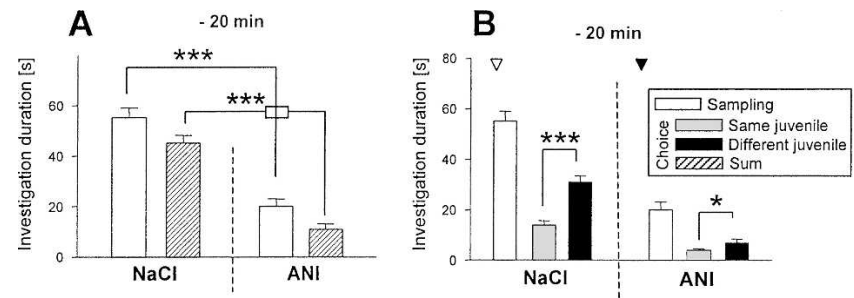

Figure 3. Effects of anisomycin (ANI) on olfactory recognition memory performance of adult male mice as tested in the social discrimination procedure. ANI was injected subcutaneously $(150 \mathrm{mg} / \mathrm{kg}$ body wt.; $\mathbf{\nabla}) 20$ min before sampling on $(A)$ the total investigatory curiosity and $(B)$ juvenile discrimination at an RI of 60 min. During the control session the animals received the same volume of sterile $\mathrm{NaCl}$ solution $(0.9 \%$; $\mathrm{NaCl}$, $\nabla)$. (A) ANI treatment significantly reduced the investigatory curiosity per se, but $(B)$ did not affect juvenile discrimination. ${ }^{*} P<0.05$, ${ }^{* * *} P<0.001$, paired Student's $t$-test.

group of animals received ANI immediately after sampling, ANI also interfered with the recognition of the previously encountered juvenile (Fig. 4B).

ANI treatment $3 \mathrm{~h}$ after sampling failed to affect social dis-
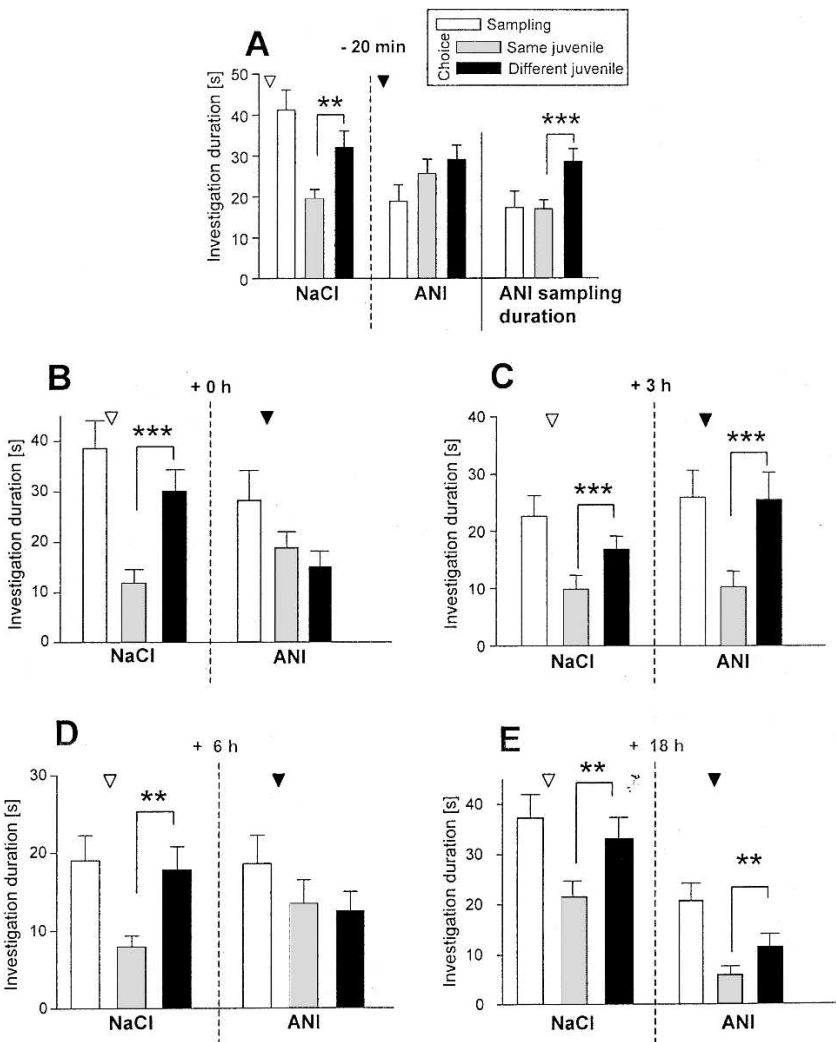

Figure 4. Effects of anisomycin (ANI) on olfactory recognition memory performance of adult male mice as tested in the social discrimination procedure. ANI was injected subcutaneously (ANI; $150 \mathrm{mg} / \mathrm{kg} \mathrm{b.} \mathrm{wt.;} \mathbf{\nabla}$ ) at different time points related to sampling on juvenile discrimination at an RI of $24 \mathrm{~h}$. ANI interfered with juvenile discrimination when applied 20 min before ( $A$; left and middle panels), immediately after $(0 \mathrm{~h} ; B$ right panel), and $6(D$; right panel) but not $3 \mathrm{~h}$ or $18 \mathrm{~h}$ ( $E$; right panel), after ( $C$; right panel) sampling. For control sessions animals received the same volume of sterile $\mathrm{NaCl}$ solution $(0.9 \% ; \mathrm{NaCl}, \nabla ; A-E$, left panels). To control for nonspecific effects of ANI treatment, an additional control session was performed for $A$. For each animal, investigation during sampling was allowed for exactly the same duration taken under ANI treatment. This restriction did not affect the juvenile discrimination abilities (right panel). ${ }^{* *} P<0.01,{ }^{* * *} P<0.001$, paired Student's $t$-test. 
crimination assessed $24 \mathrm{~h}$ after sampling (Fig. 4C). In contrast, when ANI was administered $6 \mathrm{~h}$ after sampling, it interfered with the ability of the mice to recognize a previously encountered juvenile $24 \mathrm{~h}$ after sampling (Fig. 4D). As shown in Figure 4E, treatment with ANI $18 \mathrm{~h}$ after sampling did not interfere with

\section{Fos immunoreactivity}

In the brain areas studied, Fos immunoreactivity showed a very distinctive staining that was confined to cell nuclei. We refer to the following cells in which the nucleus was positively labeled as Fos-immunoreactive cells. Nonstimulated control animals showed a very low number of Fos-immunoreactive cells. There was a significant increase in the granular and mitral cell area of the AOB (ANOVA, granular cells: interaction $F_{(2,24)}=10.37$, $P<0.01$; mitral cells: interaction $\left.F_{(2,24)}=3.87, P=0.03\right) 70 \mathrm{~min}$ after sampling-like juvenile exposure (Fig. 5A). This increase was not observed when the animals received ANI 20 min before the encounter (Fig. 5A,B). Administration of carvone failed to significantly affect the number of Fos-immunoreactive cells in the $\mathrm{AOB}$ (Figs. 5A,B, 7C). As shown in Figure 5C-E, among the other brain areas investigated, an increased number of Fos-immunoreactive juvenile recognition.

cells in response to sampling-like juvenile exposure was measured in the medial preoptic area $\left(F_{(1,20)}=14.57, P<0.01\right)$ and the medial nucleus of the amygdala $\left(F_{(2,19)}=5.36, P=0.01\right.$; Figs. $5 \mathrm{C}, 7 \mathrm{G}, \mathrm{H}, \mathrm{I})$ but not in the bed nucleus of the lateral olfactory tract and the septum (data not shown). Within the MOS juvenile exposure also increased the number of Fos-immunoreactive cells in the $\operatorname{MOB}\left(F_{(2,22)}=12.12, P<0.01\right.$; Figs. 6A, 7D) and the piriform cortex $\left(F_{(2,20)}=5.41, P=0.01\right.$; Figs. $\left.6 \mathrm{~B}, 7 \mathrm{~J}\right)$. No significant effects were measured in the cortical nucleus of the amygdala (Fig. 6C) or the hippocampal formation (Fig. 6D). In contrast, carvone application increased Fos immunoreactivity in the MOB only (ANOVA, $F_{(2,24)}=5.61, P=0.01$; Figs. 6A, 7, right panel). Interestingly, administration of control air significantly increased the number of Fos-immunoreactive cells in the piriform cortex $\left(F_{(2,20)}=5.41, P=0.01\right.$; Fig. $\left.6 \mathrm{~B}\right)$ but in no other brain area investigated (Figs. 5,6). As summarized in Figure 6E,F, samplinglike juvenile exposure activated brain areas of both the MOS and AOS, whereas carvone administration increased Fos immunoreactivity in the MOB as a part of the MOS only.

An analysis of dynamic changes over time showed that sampling-like juvenile exposure increased the number of Fosimmunoreactive cells in the AOB for at least $2 \mathrm{~h}$ and returned to basal levels after $4 \mathrm{~h}$ (granular cells: $F_{(5,25)}=8.56$, $P<0.01$; mitral cells: $F_{(5,25)}=6.55, P<0.01$; Table 1$)$. A similar time dependency was observed in the medial nucleus of the amygdala $\left(F_{(5,25)}=21.64, P<0.01\right.$; Table 1). Interestingly, in the medial preoptic area, the number of Fos-immunoreactive cells also remained elevated $4 \mathrm{~h}$ after sampling-like juvenile exposure and declined to unstimulated levels at $6 \mathrm{~h}$ $\left(F_{(5,25)}=11.81, P<0.01\right.$; Table 1$)$. In the MOB, Fosimmunoreactivity had already returned to unstimulated levels $2 \mathrm{~h}$ after sampling-like juvenile exposure (MOB: $F_{(5,25)}=11.56, P<0.01$; Table 1$)$, whereas in the piriform cortex a step-wise decrease reached unstimulated levels after $4 \mathrm{~h}\left(F_{(5,25)}=12.26, P<0.01\right.$; Table 1).

The "investigation duration" of the mice used for the immunohistochemical studies was measured; that is, the length of time each mouse spent investigating the olfactory stimulus provided. Figure 8 illustrates the investigation durations of each treatment group. Animals of all groups that experienced a sampling-like juvenile exposure showed similar investigation durations. Both carvone and control airtreated mice spent significantly more time investigating the olfactory stimulus than all groups exposed to juveniles $\left(F_{(7,30)}=2.34, P<0.05\right)$.
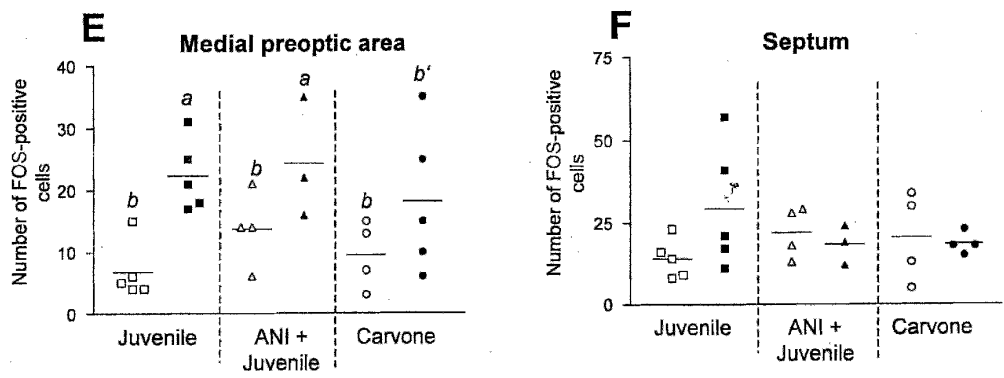

Figure 5. $(A-F)$ Number of Fos-immunoreactive cells measured in selected brain areas of the accessory olfactory system in adult male mice. Individual data and means are shown. Animals were exposed for $4 \mathrm{~min}$ to a conspecific juvenile either with a preceding injection of anisomycin (ANI; $150 \mathrm{mg} / \mathrm{kg}$ body wt.; ANI + Juvenile, middle panels) or without (Juvenile, left panels), or exposure to an airstream containing carvone (right panels). "No stimulus" animals remained undisturbed (Juvenile), or received an ANI injection only (ANI + Juvenile), or received an airstream of room air for 4 min (control for Carvone). $a, P<0.01$ vs. $b$ and $P<0.05$ vs. $b^{\prime}$; ANOVA followed by Fisher's-LSD test. $\mathrm{AOB}$, accessory olfactory bulb.

\section{Discussion}

In the present study, group-housed mice exhibited consistent recognition of previously encountered (familiar) juveniles for (at least) $24 \mathrm{~h}$. This confirms a previous report by Kogan et al. (2000) and extends the findings to C57BL/6JOlaHsd male mice. Further, here we present evidence that in the mouse the formation of long-term recognition memory for conspecifics activates Fos expression in parts of the AOS and the MOS and requires two stages of protein synthesis. As shown by our immunohistochemical data, sampling-like juvenile exposure stimulated Fos synthesis not only in the AOB but also in the medial nucleus of the amygdala and the medial preoptic area, two brain areas involved in the processing of nonvolatile olfactory stimuli (Cooke et al. 1998). In addition, we ob- 

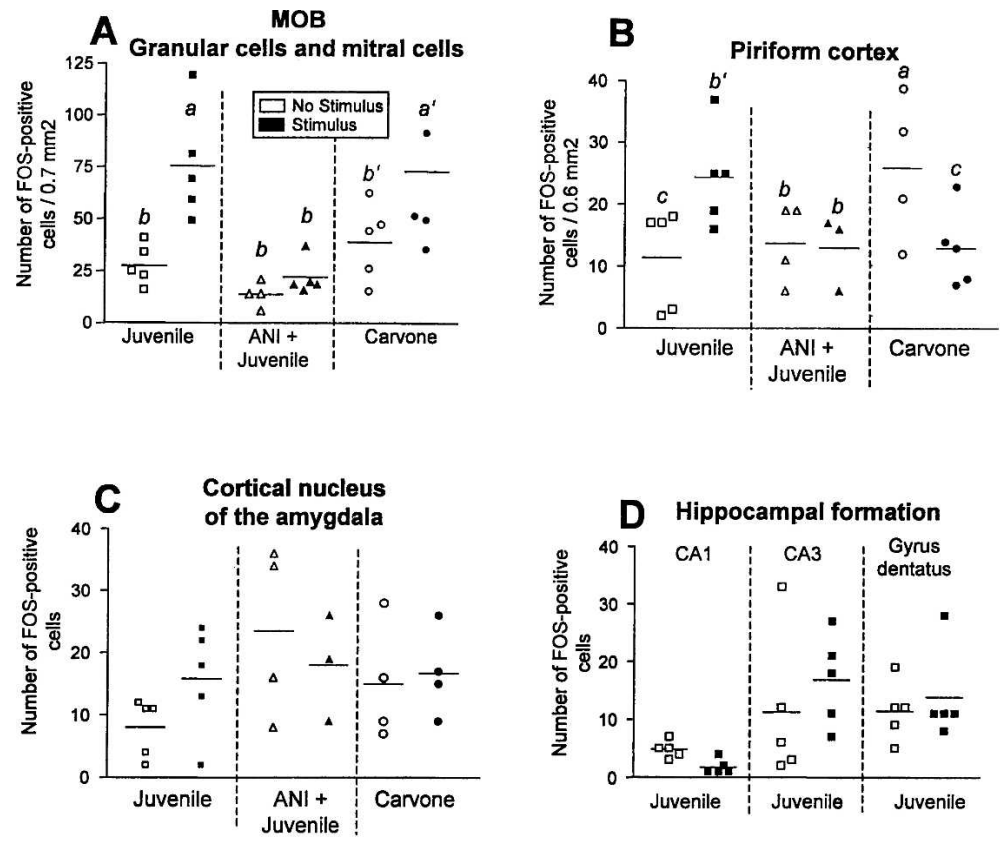

E
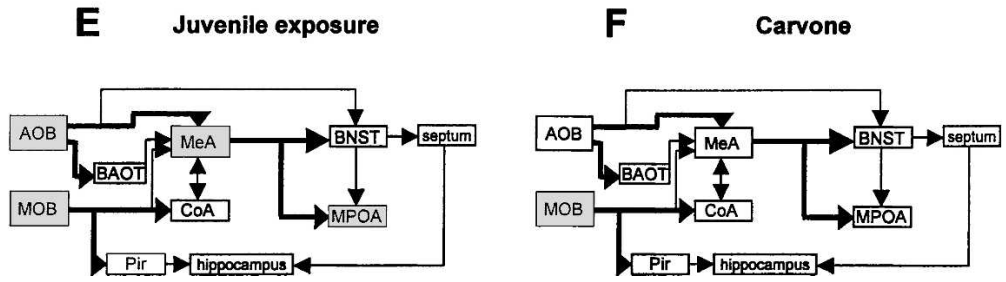

Figure 6. $(A-D)$ Number of Fos-immunoreactive cells measured in selected brain areas of the main olfactory system in adult male mice. For more details, see Figure 5 legend. $a, P<0.05$ vs. $b$ and $c ; a^{\prime}, P<0.05$ vs. $b ; b^{\prime}, P<0.05$ vs. $c$, ANOVA followed by Fisher'sLSD test. MOB, main olfactory bulb. (E,F) Activated brain areas (gray) as measured by increase in Fos-immunoreactive cells in response to $(E)$ sampling-like juvenile exposure and $(F)$ carvone exposure. Abbreviations of brain areas as in Figure 1.

served in response to sampling-like juvenile exposure an increase in Fos-positive cells in the MOB and piriform cortex. The latter findings imply that volatile signals contribute to the olfactory signature of the juvenile acquired by the adult.

These findings differ in some brain areas from those reported earlier. For example, Ferguson et al. (2001) reported an increase in Fos-immunoreactive cells in the lateral septum and bed nucleus of the stria terminalis, an effect not observed in the present study. In addition, we found an increase in Fos-immunoreactivity cells in the two neuronal subpopulations of the $\mathrm{AOB}$ and $\mathrm{MOB}$. The most obvious difference between the present study and that by Ferguson et al. (2001) is procedural. In the Ferguson study, the stimulus animals were ovariectomized females, whereas juveniles were used in the present study. Furthermore, we separated the adults only for $12 \mathrm{~h}$ (not for $7-10 \mathrm{~d}$ as in the Ferguson study) before stimulus exposure. The relatively long isolation period used by Ferguson et al. might have resulted in an increased sensitivity of both the AOS and MOS to olfactory stimuli. This would explain the increased Fos synthesis in brain areas more distant to the input site, such as the septum. In any case, our data on Fos expression suggest that the AOS and the MOS are similarly important for juvenile recognition memory in mice.

The selectivity of the juvenile exposure to stimulate Fos synthesis in brain areas of the AOS and MOS was confirmed by the immunohistochemical analysis of brains obtained from mice exposed to carvone. It was shown previously that carvone evokes a distinct activation pattern of MOB cells as measured by $\left[{ }^{14} \mathrm{C}\right] 2$-deoxyglucose uptake (Linster et al. 2001). Our results confirm that carvone does activate MOB, but not AOB cells. Interestingly, control animals for carvone treatment showed a high number of Fosimmunoreactive cells in the piriform cortex, but not the MOB. On the one hand this result supports the hypothesis that Fos immunoreactivity monitored under our conditions is specifically linked to the distinct olfactory system activated and does not merely reflect a behavioral activation. In fact carvone/control air treatment as well as juvenile exposure stimulated the investigatory and, thus, motor activity of the mice. In this context it is worth mentioning that carvone is a neutral (i.e., unconditioned) smell, whereas exposure to a juvenile has potential consequences for the animal and is, therefore, likely to be processed differently. Under these conditions, the-in comparison-extremely low "signal" to noise ratio in control air-treated animals might have resulted in an increased "sensitivity" to identify potentially relevant signals. Indeed, the experimental subjects investigated both carvone and room air for a longer duration than juveniles (Fig. 8), suggesting an attempt to identify potentially significant olfactory signals. The prolonged investigation of control air is reminiscent of some aspects of a

Table 1. Number of Fos-positive cells counted in distinct brain areas of the accessory and main olfactory systems in adult male mice under control conditions or in response to juvenile exposure after different survival times

\begin{tabular}{|c|c|c|c|c|c|c|c|}
\hline \multicolumn{2}{|c|}{ Brain area } & \multirow{2}{*}{$\frac{\text { Control }}{6.8 \pm 2.4^{\mathrm{b}}}$} & \multirow{2}{*}{$\frac{70 \min }{91 \pm 45^{a}}$} & \multirow{2}{*}{$\frac{2 \mathrm{~h}}{64.3 \pm 40^{\mathrm{a}}}$} & \multirow{2}{*}{$\frac{4 \mathrm{~h}}{26.3 \pm 15^{\mathrm{b}^{\prime}}}$} & \multirow{2}{*}{$\frac{6 \mathrm{~h}}{16.3 \pm 12^{\mathrm{b}^{\prime}}}$} & \multirow{2}{*}{$\frac{7 \mathrm{~h}}{9.17 \pm 6.6^{\mathrm{b}}}$} \\
\hline $\begin{array}{l}\text { Accessory } \\
\text { olfactory }\end{array}$ & $\begin{array}{l}\text { Granular } \\
\text { cells }\end{array}$ & & & & & & \\
\hline bulb & $\begin{array}{l}\text { Mitral } \\
\text { cells }\end{array}$ & $7.8 \pm 4.4^{b}$ & $44 \pm 29^{a^{\prime}}$ & $55.8 \pm 18^{a}$ & $29.8 \pm 21^{\mathrm{b}^{\prime \prime}}$ & $14.3 \pm 2.5^{b^{\prime}}$ & $5.5 \pm 2.4^{b}$ \\
\hline \multirow{2}{*}{\multicolumn{2}{|c|}{$\begin{array}{l}\text { Medial amygdala } \\
\text { Medial preoptic area }\end{array}$}} & $13 \pm 4.2^{b}$ & $45 \pm 18^{a}$ & $43.5 \pm 4^{a}$ & $16 \pm 6.1^{\mathrm{b}}$ & $9.67 \pm 3.5^{\mathrm{b}}$ & $8.67 \pm 2.4^{b}$ \\
\hline & & $6.8 \pm 4.7^{\mathrm{b}}$ & $22 \pm 5.7^{\mathrm{a}}$ & $19.7 \pm 8.1^{\mathrm{a}}$ & $18.7 \pm 4.7^{\mathrm{a}}$ & $7.33 \pm 1.5^{\mathrm{b}}$ & $4.5 \pm 1.9^{\mathrm{b}}$ \\
\hline \multicolumn{2}{|c|}{ Main olfactory bulb } & $28 \pm 9.8^{\mathrm{b}}$ & $75 \pm 27^{a}$ & $30.8 \pm 11^{\mathrm{b}}$ & $27.8 \pm 14^{\mathrm{b}}$ & $30.7 \pm 9.3^{b}$ & $12 \pm 2.8^{\mathrm{b}}$ \\
\hline \multicolumn{2}{|c|}{ Piriform cortex } & $11 \pm 8.1^{c}$ & $24 \pm 8^{a}$ & $17 \pm 3.6^{\mathrm{b}}$ & $5.33 \pm 2^{c}$ & $5.33 \pm 2.3^{c}$ & $5.33 \pm 2.3^{c}$ \\
\hline
\end{tabular}

Data are means \pm S.E.M.

${ }^{a} P<0.01$ vs. ${ }^{b}$ and ${ }^{c}$ and $P<0.05$ vs. ${ }^{b^{\prime}}$ and ${ }^{b^{\prime \prime}}$

$\mathrm{a}^{\prime} P<0.01$ vs. ${ }^{\mathrm{b}}$ and $P<0.05$ vs. ${ }^{\mathrm{b}^{\prime}}$.

${ }^{b} P<0.01$ vs. ${ }^{c}$, ANOVA followed by Fisher's-LSD test.

\section{Learning \& Memory www.learnmem.org}


phenomenon known as Eigengrau, described for the visual system to explain the subjective perception of gray after adaptation to a dark room (Aubert 1865).

Other authors have reported that female odor exposure failed to cause detectable changes in the medial preoptic area in male rats as measured by the deoxyglucose technique (Orsini et al. 1985). We, however, observed a significant increase in Fosimmunoreactive cells which-in contrast to the other brain areas analyzed-also remained elevated after $4 \mathrm{~h}$, reaching control levels at $6 \mathrm{~h}$. The increased Fos expression in the medial preoptic area supports the hypothesis that this brain structure is specifically involved in the emotional processing of olfactory stimuli in rodents (Paolini and McKenzie 1996; Walsh et al. 1996) and undergoes plastic changes (Fewell and Meredith 2002) related to the formation of the long-term recognition memory rather than serving as a relay station only.

Aversive stimulation has been shown to induce a second stage of protein synthesis that reaches a significantly increased level 4-8 h after stimulus presentation (Grecksch and Matthies 1980; Freeman et al. 1995; Quevedo et al. 1999; Ressler et al. 2002). Therefore, we administered ANI at 3, 6, and $18 \mathrm{~h}$ after sampling. Although ANI treatment $3 \mathrm{~h}$ after sampling failed to affect the olfactory memory performance assessed after $24 \mathrm{~h}$, inhibition of protein synthesis $6 \mathrm{~h}$ after sampling interfered with juvenile recognition. This demonstrates that long-term olfactory recognition memory in mice requires at least two stages of protein synthesis: one starting immediately after sampling and the second 6-7 h later. Protein synthesis seems to finish not later
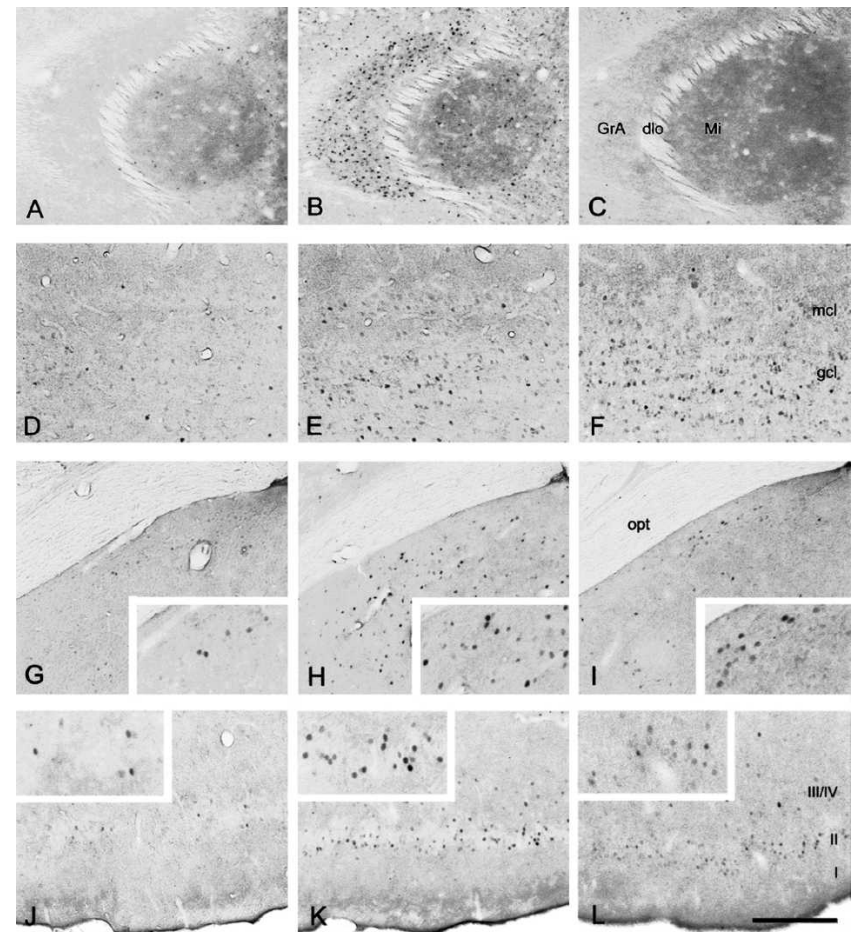

Figure 7. Representative microphotographs of Fos immunoreactivity in brain slices of adult male mice that were killed either unstimulated (left panel), 70 min after sampling-like juvenile exposure (middle panel), or 70 min after carvone exposure (right panel). The figure shows $(A-C)$ the accessory olfactory bulb, $(D-F)$ the main olfactory bulb, $(G-l)$ the medial amygdala, and $(J-L)$ the piriform cortex. GrA, granule cell layer of the accessory olfactory bulb; dlo, dorsolateral olfactory tract; Mi, mitral cell layer of the accessory olfactory bulb; $\mathrm{mcl}$, mitral cell layer of the olfactory bulb; gcl, granule cell layer of the olfactory bulb; opt, optic tract; I, II, III/IV, layers of the piriform cortex. Scale: $G-L, 300 \mu \mathrm{m} ; A-F$ and insets, $150 \mu \mathrm{m}$.

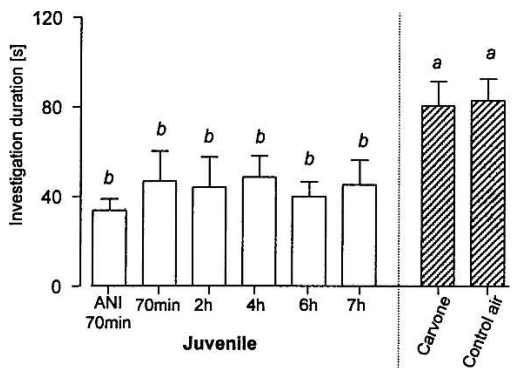

Figure 8. Investigation duration of stimuli presented to the male mice used for immunohistochemical studies (means \pm SEM) and that were exposed for 4 min either to a conspecific juvenile and killed 70 min (with or without ANI pretreatment) or 2, 4, 6, or $7 \mathrm{~h}$ later or were exposed to an airstream containing carvone or room air only and killed 70 min later. $a, P<0.05$ vs. $b$; ANOVA followed by Fisher's-LSD test.

than $18 \mathrm{~h}$ after sampling, since ANI treatment at this time point failed to interfere with the juvenile recognition (Fig. 4E). Between the two stages, olfactory recognition memory is insensitive to the protein synthesis blocker ANI, which coincides with the decline of the number of Fos-positive neurons in the brain areas under study. Furthermore, the second stage of protein synthesis is-in contrast to the first stage-not paralleled by increased Fos synthesis. The results of our ANI treatment experiments suggest that the essential function of the second stage of protein synthesis depends upon the integrity of the first stage of protein synthesis. Biphasic responses have been reported for the phosphorylation of other transcription factors under aversive stimulation (BilangBleuel et al. 2002). Thus, it is likely that the second stage of protein synthesis involved in long-term olfactory recognition memory includes the synthesis of proteins that are necessary for enhanced intercellular communication.

Taken together, the data of the present study suggest that nonassociative, long-lasting olfactory recognition memory requires-similarly to associative memory-at least two stages of protein synthesis. The first stage coincides with an increase in the number of Fos-immunoreactive cells in brain areas associated predominantly with the AOS. During the second stage, proteins other than Fos are synthesized that seem to be essential for olfactory engram formation.

\section{Materials and Methods}

\section{Animals}

Adult male C57BL/6JOlaHsd mice (9-16 wks old; HarlanWinkelmann) were used as experimental subjects. They were housed in groups of five per cage (size $20 \times 37 \times 15 \mathrm{~cm}$ ) under standard laboratory conditions with a $12 \mathrm{~h}$ light/12 h dark cycle (light on: 07:00) for $1 \mathrm{wk}$ before starting the experiments. Juvenile mice of both sexes (25-30 d old) were used as olfactory stimuli.

All experimental manipulations were approved by the Committee on Animal Health and Care of the local governmental body and performed in strict compliance with the EEC recommendations for the care and use of laboratory animals (86/609/ CEE).

\section{Olfactory recognition}

Olfactory recognition was tested using the social discrimination procedure adapted from rat studies (Engelmann et al. 1995) during the beginning of the light phase (between 8:00 and 12:00 a.m.). Briefly, experimental subjects were separated by transferring them to fresh small cages (size $14 \times 20 \times 15 \mathrm{~cm}$ ) $2 \mathrm{~h}$ before starting the session. A social discrimination session consisted of two 4-min exposures of juveniles to the adult in the adult's cage (Fig. 2A). During the first exposure ("sampling") a juvenile was 
exposed to the adult animal, and the duration of investigatory behavior of the adult towards the juvenile (mainly sniffing and licking of the anogenital region of the juvenile) was recorded by a trained observer blind to the animal's treatment, with the help of a program running on a personal computer. The juvenile was then removed and kept individually in a fresh cage with food and water available ad libitum. After a defined retention interval (RI) of $60 \mathrm{~min}$, or $24 \mathrm{~h}$, the juvenile was re-exposed to the adult (second exposure; "choice") but this time together with an additional, previously not presented juvenile of the same mouse strain. The duration of investigatory behavior of the adult towards each juvenile was measured separately. A significantly longer investigation duration of the new juvenile compared to the familiar juvenile (i.e., the conspecific previously presented during the sampling phase) was taken as an evidence for an intact recognition memory (Engelmann et al. 1995). After each session, the experimental subjects were housed in their original groups of five.

An important technical aspect needs to be mentioned for a proper interpretation of the data. We performed the experimental sessions during the light phase and, therefore, during the inactive phase of the mice. This time window was chosen to allow the subsequent investigation of Fos synthesis in detail in the second part of the study. Testing the animals during their inactive phase has the advantage that those neuronal systems which are required to perform the task are primarily activated. This minimizes the number of other neuronal populations that unequivocally would have been activated during the more active phase, such as brain areas implicated in eating, drinking, and general motor activity (Herbert et al. 1992; Wang et al. 1996; Nagahara and Handa 1997; Horn and Friedman 1998; Rhodes et al. 2003; Sinnayah et al. 2003). However, as a consequence the investigation duration during sampling is lower compared to sessions held during the more active phase of the animals.

\section{Fos immunoreactivity}

For analyzing Fos immunoreactivity, experimental subjects $(n=45)$ were separated $12 \mathrm{~h}$ prior to the olfactory stimulation. Olfactory stimuli were presented for 4 min between 7:00 a.m. and 10:00 a.m. Mice were exposed either to a 25-30-d-old juvenile of the same strain (sampling-like juvenile exposure) or to (S)-(+)carvone diluted 1:1 in dietylphthalate (both from Dr. T. Suchardt). In the latter case a cotton tip soaked with $25 \mu \mathrm{L}$ of the carvone solution was put into an airstream that was produced by a silent computer cooling fan and directed to the head of the animal. The concentration of carvone was chosen according to the activity of $\mathrm{C} 57 \mathrm{BL} / 6 \mathrm{JOlaHsd}$ mice to recognize carvone versus anethole, linaloole, and isoamyl acetate in an olfactory cue discrimination task without being appetitive or aversive to the animals (C. Fentrop, pers. comm.). Controls remained undisturbed in their cages (sampling-like juvenile exposure) or received dietylphthalate only as a control for carvone administration. During the presentation of the olfactory stimuli, a trained observer measured the duration of investigatory behavior of the adult mice towards the presented stimulus.

Seventy minutes (and in case of sampling-like juvenile exposure also $2,4,6$, and $7 \mathrm{~h}$ ) after administration of the olfactory stimuli, adults were deeply anesthetized using a mixture of 0.1 $\mathrm{mL} / 0.06 \mathrm{~mL}$ Ketavet and Dormitor (Pharmacia, Bayer Vital, respectively) and transcardially perfused with physiological saline for $2 \mathrm{~min}$ followed by $4 \%$ formaldehyde, diluted in $0.1 \mathrm{M}$ phosphate buffer $\mathrm{pH} 7.4$ (PB) for $12 \mathrm{~min}$. Brains were removed, postfixed for $20 \mathrm{~h}$ in $4 \%$ formaldehyde diluted in PB, transferred to $0.5 \mathrm{M}$ sucrose in PB for $6 \mathrm{~h}$ and finally to $1 \mathrm{M}$ sucrose in PB for $\sim 40 \mathrm{~h}$. The brains were shock-frozen in isopentanol at $-50^{\circ} \mathrm{C}$ and stored at $-80^{\circ} \mathrm{C}$ until cryosectioning (Leica Frigocut $2800 \mathrm{E}$, Wetzlar). Floating frontal sections $(25 \mu \mathrm{m})$ were incubated with an antibody raised against a peptide mapping at the amino terminus of human c-Fos p62 (identical to the corresponding mouse sequence; c-Fos sc-42; Santa Cruz Biotechnology). Immunoreactive cells were visualized using the ABC-method as described (Laube et al. 2002). The number of Fos-immunoreactive cells was deter- mined using a Zeiss microscope (Axiophot) and a computer software program (Image C). The following brain areas were identified using the stereotaxic atlas of Franklin and Paxinos (1997): AOB (granular and mitral cell subdivisions), MOB, medial nucleus of the amygdala, piriform cortex, medial preoptic area, and the dorsal part of the hippocampal formation (CA1, CA3 subdivisions and dentate gyrus). A trained observer unaware of the animal's treatment counted all cells that were immunoreactive in a given brain area on 1-3 representative slices per animal. For the $\mathrm{MOB}$, a representative area of $0.7 \mathrm{~mm}^{2}$ (including both mitral and granular cells) was analyzed.

\section{Blockade of protein synthesis}

Protein synthesis was blocked by anisomycin (ANI; SigmaAldrich) diluted in saline by adding $0.1 \mathrm{M} \mathrm{HCl}$. The $\mathrm{pH} 7.2$ was adjusted by $0.1 \mathrm{M} \mathrm{NaOH}$. Animals received ANI (150 mg/kg subcutaneous) under light isofluran (Forene, Abbott) anesthesia 20 min before (social discrimination; Fos immunohistochemistry) or immediately after, or 3,6 , or $18 \mathrm{~h}$ after the sampling period (the first exposure to the juvenile). The dosage used here was shown previously to reduce protein synthesis to $<10 \%$ for the first $2 \mathrm{~h}$ after administration and to $<40 \%$ for the following $2 \mathrm{~h}$ (Flood et al. 1973). A total of five groups of animals $(n=10-20$ each) were used. Each group of animals was tested in multiple sessions. During control sessions, animals received the same volume of sterile saline. Experiments were performed in a balanced cross-over design with 1 wk between two successive treatments.

\section{Statistics}

Data are presented either as means + / - SEM (investigation durations during social discrimination) or as individual data with mean (number of Fos-immunoreactive cells). The statistical analysis was performed using GB-STAT 6.0 (Dynamic Microsystems) or GraphPad Prism 4.01 (GraphPad Software). Data obtained from the social discrimination were analyzed using the paired Student's $t$-test. The number of Fos-immunoreactive cells was analyzed either with a two-factor randomized ANOVA (stimulus $\times$ treatment; different olfactory stimuli) or a one-factor ANOVA (time after sampling). Investigation durations of the animals used subsequently for immunohistochemistry were analyzed by one-factor ANOVA. ANOVAs were followed by Fisher's LSD-test if appropriate. A $P<0.05$ was considered statistically significant.

\section{Acknowledgments}

We thank Andrea Rudloff and Rita Murau for expert technical support, and Dr. Carsten T. Wotjak (Max-Planck-Institut für Psychiatrie) and Dr. Charles Heyser (Franklin \& Marshall College) for their valuable comments on this manuscript. Supported by DFG.

\section{References}

Aubert, H. 1865. Physiologie der Netzhaut. Morgenstern, Breslau.

Beckett, S.R., Duxon, M.S., Aspley, S., and Marsden, C.A. 1997. Central c-fos expression following $20 \mathrm{kHz} /$ ultrasound induced defence behaviour in the rat. Brain Res. Bull. 42: 421-426.

Bilang-Bleuel, A., Rech, J., De Carli, S., Holsboer, F., and Reul, J.M. 2002. Forced swimming evokes a biphasic response in CREB phosphorylation in extrahypothalamic limbic and neocortical brain structures in the rat. Eur. J. Neurosci. 15: 1048-1060.

Cooke, B., Hegstrom, C.D., Villeneuve, L.S., and Breedlove, S.M. 1998. Sexual differentiation of the vertebrate brain: Principles and mechanisms. Front. Neuroendocrinol. 19: 323-362.

Dantzer, R., Bluthe, R.M., Koob, G.F., and Le Moal, M. 1987. Modulation of social memory in male rats by neurohypophyseal peptides. Psychopharmacology (Berl). 91: 363-368.

Duncan, G.E., Knapp, D.J., and Breese, G.R. 1996. Neuroanatomical characterization of Fos induction in rat behavioral models of anxiety. Brain Res. 713: 79-91.

Eibl-Eibesfeldt, I. 1950. Beiträge zur Biologie der Haus- und Ährenmaus nebst einigen Beobachtungen an anderen Nagern. Z. Tierpsychol. 7: 558-587.

Eibl-Eibesfeldt, I. 1952. Ethologische Unterschiede zwischen Hausratte und Wanderratte. Verh. Deutsch. Zool. Ges. Freiburg 169-180.

\section{Learning \& Memory}


Engelmann, M., Wotjak, C.T., and Landgraf, R. 1995. Social discrimination procedure: An alternative method to investigate juvenile recognition abilities in rats. Physiol. Behav. 58: 315-321.

Ferguson, J.N., Aldag, J.M., Insel, T.R., and Young, L.J. 2001. Oxytocin in the medial amygdala is essential for social recognition in the mouse. J. Neurosci. 21: 8278-8285.

Fewell, G.D. and Meredith, M. 2002. Experience facilitates vomeronasal and olfactory influence on Fos expression in medial preoptic area during pheromone exposure or mating in male hamsters. Brain Res. 941: $91-106$.

Flood, J.F., Rosenzweig, M.R., Bennett, E.L., and Orme, A.E. 1973. The influence of duration of protein synthesis inhibition on memory. Physiol. Behav. 10: 555-562.

Franklin, K.B.J. and Paxinos, G. 1997. The mouse brain in stereotaxic coordinates. Academic Press, San Diego, CA.

Freeman, F.M., Rose, S.P., and Scholey, A.B. 1995. Two time windows of anisomycin-induced amnesia for passive avoidance training in the day-old chick. Neurobiol. Learn. Mem. 63: 291-295.

Grecksch, G., and Matthies, H. 1980. Two sensitive periods for the amnesic effect of anisomycin. Pharmacol. Biochem. Behav. 12: $663-665$.

Herbert, J., Forsling, M.L., Howes, S.R., Stacey, P.M., and Shiers, H.M. 1992. Regional expression of c-fos antigen in the basal forebrain following intraventricular infusions of angiotensin and its modulation by drinking either water or saline. Neuroscience 51: $867-882$.

Horn, C.C. and Friedman, M.I. 1998. Metabolic inhibition increases feeding and brain Fos-like immunoreactivity as a function of diet. Am. J. Physiol. 275: R448-R459.

Imaki, T., Shibasaki, T., Hotta, M., and Demura, H. 1993. Intracerebroventricular administration of corticotropin-releasing factor induces c-fos mRNA expression in brain regions related to stress responses: Comparison with pattern of c-fos mRNA induction after stress. Brain Res. 616: 114-125.

Kogan, J.H., Frankland, P.W., and Silva, A.J. 2000. Long-term memory underlying hippocampus-dependent social recognition in mice. Hippocampus 10: 47-56.

Laube, G., Seidenbecher, C.I., Richter, K., Dieterich, D.C., Hoffmann, B., Landwehr, M., Smalla, K.H., Winter, C., Bockers, T.M., Wolf, G., et al. 2002. The neuron-specific $\mathrm{Ca}^{2+}$-binding protein caldendrin: Gene structure, splice isoforms, and expression in the rat central nervous system. Mol. Cell Neurosci. 19: 459-475.

Linster, C., Johnson, B.A., Yue, E., Morse, A., Xu, Z., Hingco, E.E., Choi, Y., Choi, M., Messiha, A., and Leon, M. 2001. Perceptual correlates of neural representations evoked by odorant enantiomers. $J$.
Neurosci. 21: 9837-9843.

Nagahara, A.H. and Handa, R.J. 1997. Age-related changes in c-fos mRNA induction after open-field exposure in the rat brain. Neurobiol. Aging 18: 45-55.

Orsini, J.C., Jourdan, F., Cooper, H.M., and Monmaur, P. 1985. Influence of female odors on lateral hypothalamus in the male rat. Semiquantitative deoxyglucose analysis. Physiol. Behav. 35: 509-516.

Paolini, A.G. and McKenzie, J.S. 1996. Lesions in the magnocellular preoptic nucleus decrease olfactory investigation in rats. Behav. Brain Res. 81: 223-231.

Quevedo, J., Vianna, M.R., Roesler, R., de-Paris, F., Izquierdo, I., and Rose, S.P. 1999. Two time windows of anisomycin-induced amnesia for inhibitory avoidance training in rats: Protection from amnesia by pretraining but not pre-exposure to the task apparatus. Learn. Mem. 6: 600-607.

Ressler, K.J., Paschall, G., Zhou, X.L., and Davis, M. 2002. Regulation of synaptic plasticity genes during consolidation of fear conditioning. $J$. Neurosci. 22: 7892-7902.

Rhodes, J.S., Garland Jr., T., and Gammie, S.C. 2003. Patterns of brain activity associated with variation in voluntary wheel-running behavior. Behav. Neurosci. 117: 1243-1256.

Rose, S.P. 1995. Cell-adhesion molecules, glucocorticoids and long-term-memory formation. Trends Neurosci. 18: 502-506.

Rose, S.P. and Stewart, M.G. 1999. Cellular correlates of stages of memory formation in the chick following passive avoidance training. Behav. Brain Res. 98: 237-243.

Sagar, S.M., Sharp, F.R., and Curran, T. 1988. Expression of c-fos protein in brain: Metabolic mapping at the cellular level. Science. 240: $1328-1331$.

Sinnayah, P., Blair-West, J.R., McBurnie, M.I., McKinley, M.J., Oldfield, B.J., Rivier, J., Vale, W.W., Walker, L.L., Weisinger, R.S., and Denton, D.A. 2003. The effect of urocortin on ingestive behaviours and brain Fos immunoreactivity in mice. Eur. J. Neurosci. 18: 373-382.

Walsh, C.J., Fleming, A.S., Lee, A., and Magnusson, J.E. 1996. The effects of olfactory and somatosensory desensitization on Fos-like immunoreactivity in the brains of pup-exposed postpartum rats. Behav. Neurosci. 110: 134-153.

Wang, Y., Cummings, S.L., and Gietzen, D.W. 1996. Temporal-spatial pattern of c-fos expression in the rat brain in response to indispensable amino acid deficiency. I. The initial recognition phase. Brain Res. Mol. Brain Res. 40: 27-34.

Received February 1, 2005; accepted in revised form June 14, 2005. 


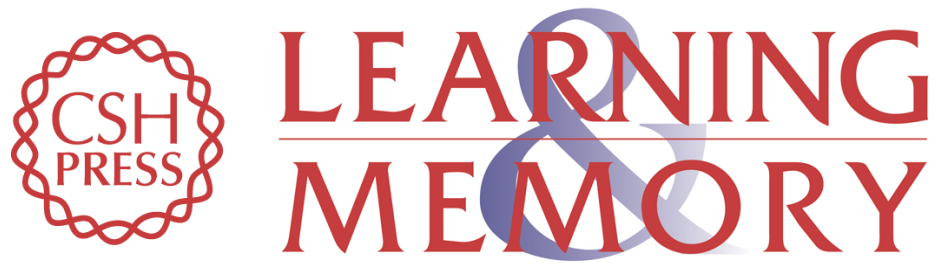

\section{Social recognition memory requires two stages of protein synthesis in mice}

Karin Richter, Gerald Wolf and Mario Engelmann

Learn. Mem. 2005, 12:

Access the most recent version at doi:10.1101/lm.97505

References This article cites 29 articles, 5 of which can be accessed free at:

http://learnmem.cshlp.org/content/12/4/407.full.html\#ref-list-1

License

Email Alerting Receive free email alerts when new articles cite this article - sign up in the box at the Service top right corner of the article or click here. 